ARTICLE

\title{
Chutneyed Poetics: Reading Diaspora and Sundar Popo's Chutney Lyrics as Indo-Caribbean Postcolonial Literature
}

\author{
Rajiv Mohabir \\ Auburn University, US \\ rajiv.mohabir@gmail.com
}

It is my intent for these new readings of Sundar Popo's song lyrics to not only challenge modern epistemic violence perpetrated against the deemed frivolity of Chutney (as a genre's) lyrics, but also to utilize the original texts to understand these songs as an essential postcolonial Indo-Caribbean literature. Since the archive of Caribbean literature includes predominantly English, Spanish, French, and various nation languages, I posit the inclusion of Caribbean Hindi as a neglected archive is worth exploring given its rich significations as literature. I engage chutney music, a form of popular music, as poetry to illustrate the construction of Indo-Caribbean identity through the linguistic and poetic features of its lyrics as a cultural production that are created by the syncretisms of the Caribbean. This paper is written in four sections: 1. A Chutneyed Diaspora, 2. Methods and Approach, 3. Chutney Translation and Analysis: Bends Towards Meaning and 4. Diaspora as Chutney.

The first section provides a historical stage for the emergence of Chutney music, concentrating on an introduction to the trends of its study by contemporary ethnomusicologists. The second section introduces my own approach to the study of oral traditions as literature and my engagement with my subjective postcolonial positioning as an individual of Indo-Caribbean origin. The third section is a close reading, a deeper look into meaning conveyed by these earlier dismissed lyrics. It attempts to illustrate an ethos thriving in Sunder Popo's generation of cultural syncretism and linguistic identity. The last section endeavors to conclude this study by positing that Indian-ness itself, its tropes and culturalisms, becomes a type of Chutney by virtue of its syncretic nature. Moreover, it serves as an indication that these transformations of folk music are not cultural remnants, but rather a new expression of Indo-Caribbean identity.

Keywords: chutney; Indian; soca

"Cultural identities come from somewhere, have histories. But, like everything which is historical they undergo constant transformation. Far from being eternally fixed in some essentialised past, they are subject to the continuous "play" of history, culture and power. Far from being grounded

in mere 'recovery' of the past which is waiting to be found, and which when found, will secure our sense of ourselves into eternity, identities are the names we give to the different ways we are positioned by, and position ourselves within, the narratives of the past."

Stuart Hall, "Cultural Identity and Diaspora"

uhi re babur ban par gayal hī dịle nā sās jhulawe sasurwā ke ab na jaibe babur ban mẽ jiyāra jar gayal hamar Sundar Popo, "Ab Na Jaibe" 


\section{A Chutneyed Diaspora}

Between the years of 1838 to 1917, about 238,960 East Indians were brought to Guyana under the new system of slavery devised by the British, called "indenture," to work the sugarcane field of the new colonies. Of this number only 75,236 received return passage to India after their renewable five-year contracts were over (Vatuk, "Craving for a Child" 55). The majority of the Indians brought to the Caribbean were Bhojpuri speakers from the states of Eastern Uttar Pradesh (then the United Provinces) and Bihar, then the poorest of the provinces under colonial rule. They were enticed and forced (Mesthrie 46) into laboring abroad through "deception, trickery, blackmail and even kidnapping" (Vatuk, "Protest Songs" 224), with promises of return passage and a living wage if they signed five-year renewable contracts. With them they brought their various North Indian languages that were then koined into a vernacular. The laborers called this new language "Hindustani," and it is referred to today as Caribbean Hindi, or specifically Guyanese Bhojpuri or Trinidadian Bhojpuri (Gambhir 80).

Gambhir in his study of The East Indian Speech Community of Guyana, describes the process of koinization as a blending of lexicon and grammatical features to suit the various speech communities present in the new context. The amalgamation of North Indian languages undergoes editing and changes for the express purpose of communication with the specific laboring class in forced Diaspora. This linguistic process also serves as a metaphor for the type of music produced by the descendants of these original laborers. Linguistically, the East Indians underwent a language change after two generations with semantic shifts occurring to facilitate inter-linguistic communication. It was in this generation that English was introduced as the language of power and a Creole developed from the earlier Pidgin language.

The East India Company sponsored the landowners of the sugarcane plantations to feed a growing need for the sweetener. This was because English climate was inhospitable for sugar cane cultivation. The interaction between the language of power and the language of the laborers spawned the development of a Pidgin that grew into Trinidadian English Creole. Each older generation of Creole remains closer to the original language of the Pidgin. After several generations Bhojpuri fell into disuse, maintaining only a secondary importance in ritual space and in kinship terms. It was in this linguistic climate that the singer Sundar Popo, according to a personal interview conducted in 1996 by Tina Ramanarine, learned Bhojpuri songs from the women in his family (Ramnarine, "Historical Representations" 13).

My mother had a group of ladies who used to sing at the farewell night [part of the wedding ceremony]. As young children, they couldn't leave us home so they took us with them ... (Sundar Popo qtd. Ramnarine 13)

He experimented with a new syncretic style that blended English, Creole, Bhojpuri, and Hindi languages to express his unique linguistic identity and poetics that arose in the space of contact that is the Caribbean. He was able to use English in his music in order to reach a growing English dominant audience while maintaining sonorous and thematic ties to a local koined variety of Indian-ness. A truism that can be conceptualized in postcolonial theory as Tiffin posits,

Post-colonial cultures are inevitably hybridized, involving a dialectical relationship between European ontology and epistemology and the impulse to create or recreate independent local identity. (Tiffin 99)

Chutney music is the fast paced, sometimes ribald, dance music of Indo-Caribbean communities named for the popular condiment of mango and hot peppers. Chutney, my own familial recipe, includes the mashing of a green mango (we never say "unripened"), cherry peppers, and the inclusion of roasted spices all submerged in a bath of mustard oil. There is no one ingredient that is expendable, in fact the whole creation of the condiment is contingent on the correct proportions of cumin, mustard, spice and fruit. Likewise, this genre of music is aptly named and described as Chutney because it combines many different Caribbean elements in its making. The instruments used to produce this music are essential and also serve as metaphors for "Indian-ness" while often beating Soca and Calypso themed rhythms.

The songs draw its themes and features from a syncretism of Soca, Reggae, and traditional Bhojpuri folksongs such as matkor, chautal, biraha, and lachari-all Indian folk traditions. The song texts are from various sources: learned from older generations, and newly written lyrics. The themes of the songs, according to ethnomusicologist Peter Manuel, "generally adhere to stock Indian folksong themes" about Krishna and the cowherd girls, a wife complaining about her in-laws, or about erotic encounters (Manuel "Construction of 
Diaspora" 28). Its importance, as well as the Bhangra phenomenon in South Asian immigrant and Diasporic communities is paramount as it has become a multinational industry with performers living in North America, Europe, India, and the Caribbean. The evolution of Chutney music passed from Bhojpuri lyrics, to combined English and Bhojpuri, to English lyrics that retain the same telltale rhythm described by Manuel and iconic instrumentation. Traditional instruments include the harmonium, the dholak, dhantal, and the human voice. In contemporary Chutney music of Drupatee, Rikki Jai, Terry Gajraj and others, electronic instruments such as synthesizers and drum machines are ubiquitous.

The creation of chutney music as a genre hails Sundar Popo (1943-2000) as the one of the first singers, and sometimes originator of the Chutney genre in 1973 (Ramnarine, "Historical Representations" 13). This elicits a new origin myth of the creator of Chutney music. However, the style's actual origin is a contentious case in the study of ethnomusicology. Ramnarine and Manuel both have differing accounts of the origins of the music as coming from the homosocial women's wedding-time matkor space; Manuel purports that Chutney as a genre originated from a synthesis of various species of Bhojpuri folksong. Even the origins of the instruments are shrouded in mystery as academics do not agree on, for example: the dantal's genesis. The dantal is a percussive metal rod and striking implement (danda meaning stick in Hindi and tāla meaning rhythm), with some theorists positioning its origin in South Asian and others suggesting it is a creation of need from the musicians redefining their musical culture in diaspora.

Commonly, when regarding Caribbean literature, the more available colonial languages of Spanish, French, English and their nation language Creoles represent an archive of literary production, as is the case in TorresSaillant's Caribbean Poetics: Toward an Aesthetic of West Indian Literature. What I am arguing is that cultural production in the Caribbean must be understood to embody the same discursive space as literature since most of the people who were enslaved, invaded, or indentured to come to the Caribbean represented various oral cultures. I am also positing that chutney music is syncretic and cannot be separated from Caribbean space. The Caribbean is a place of creation. This acknowledged, what is not as readily available in Caribbean literary studies is the presence of Caribbean Hindi and the music-literature that has shaped the landscape of the diasporic imaginary.

When regarding Soca-Chutney music as an archive of Indo-Caribbean thought, its relationship to gender, nation-state, and calypso music Tejaswini Niranjana in her book Mobilizing India: Women, Music, and Migration Between India and Trinidad looks at public space and performance of music, Niranjana charts SocaChutney's development as music in the public sphere and its implications on the East Indian woman's body. Niranjana sums up by stating,

understanding of the discourses and practices of nationalist modernity, and the formation of modern subjectivities ... could be deepened by (1) an investigation of the processes by which subaltern migrants are disavowed; and (2) an inquiry into contemporary cultural practices of those migrants. I argue that indentureship enabled a different sort of access to modernity for the subaltern diaspora from that which was being consolidated in India is the late nineteenth century and early twentieth century ... in terms of organizational production and ways of living the first "modern" society in the history of the world. Indentured laborers, both men and women, therefore entered into a capitalist system of production long before most of their counterparts in India. Moreover, they entered a system that had already created, through slavery, modern subjects who were not of Western origin. (Niranjana 22-23)

Niranjana's text puzzles out the complicated race relations in Trinidad by reading Soca-Chutney song lyrics as a type of literature and shows intertextuality between Calypso and Soca-Chutney. The hostilities between African and Indian descendants in Trinidad were produced, according to Niranjana, by colonial measures that ensured the squashing of any possible solidarity building between groups. By doing so the British had affected a chain of results that made the construction of the Indian woman as bearer of East Indian Trinidadian culture, which also shaped the discourse of Indian women in India. Niranjana also charts the way Chutney music troubles the elite Indian classes of Trinidad in that it is not atavistically reflective of "high" Indian culture-but rather exposes the "low" culture of the Coolie. Niranjana's exploration is indeed cogent in her analysis of Caribbean space, cultural production, and diffusion of ideas, however, her archive relies on a mostly English and Trinidad English Creole, ignoring the Caribbean Hindi and Bhojpuri language music in her discussion.

There are two main ways that academics have framed their research regarding the study of Diasporic communities: the first being through the preservationist lens and the second through a cultural creative model. 
Aisha Khan, in her study of "Juthaa in Trinidad: food, pollution, and hierarchy in a Caribbean Diaspora community" typifies the first as a "search for cultural heritage through 'survivals' (or 'retentions') and reinterpretations" (Khan 246). Manuel and Ramnarine refute this using a postcolonial lens to determine the origins and to progress to a discussion of local traditions and identities. Manuel says that "chutney "constitutes a revival and repackaging' of various folk genres" (Ramnarine, "Historical Representations" 3). Here Chutney music's kinship ties to its precursor folk genres are culturally adaptive instead of static cultural "survivals." These new sycretisms construct new subjectivities by way of their chutneyed parts instead of pandering to discussions of cultural erosion.

The musical production of Chutney has been well documented as well as the English lyrics of various popular Chutney songs. Despite this, there has not yet been an in-depth analysis of the Bhojpuri poetics of the older Chutney lyrics, the parent of and caregiver to contemporary Chutney music. Helen Meyers discusses some meanings and social contexts of Bhojpuri music in her book Music of Hindu Trinidad: Songs of the Indian Diaspora but does not expound on the significations and tropes that create Chutney poetics. In fact, Manuel in his article "Chutney and Indo-Trinidadian Cultural Identity" states that,

If soca song texts are generally unimportant by virtue of their brevity and triviality, Chutney lyrics are semantically insignificant because of their conventionality and, more obviously, because of the fact that they are sung in a language (Bhojpuri Hindi) which is largely unintelligible to most IndoTrinidadians and Guyanese. (28)

Reducing the importance and the poetics of Indo-Caribbean folksongs, be they in a heritage language or in the spoken Creole, is a form of epistemic violence that ignores their function. Caribbean Hindi/Bhojpuri Chutney music encodes a Diasporic poetics that discusses identity and desire. Even though Bhojpuri and Hindi are no longer first languages of most Indo-Caribbean people, South Asian language plays an invaluable role in a community's self identification, creation and maintenance of Diasporic local "Indian-nesses."

In this way the lyrics of Sundar Popo's Chutney songs become a literature, a poetry in which there is evidence of Diasporic syncretism that engages a community in mid-shift from Bhojpuri language dominance to English dominance. This also includes the shifting of the poetics of place to include the poetic journeys of dislocation and relocation. Evident in this poetry are the tensions of language, symbolism and overall theory of construction based in a unique living oral, performative tradition. Before this dialogue can occur, an important consideration is the understanding of Diasporic creations of Indian-ness as "authentic," occurring on their own terms of conceptions of identity-in this way there is no location of the ancestral homeland "India" outside of its Diasporic community. For example, there is no need to look to the Indian subcontinent for answers to endemic questions of Indo-Caribbean community and its musical traditions. Some scholars posit that "Indian" traditions in Diaspora are more "authentic" than those in India (Manuel, "Construction of Diasporic Tradition" 27). While this is true, there are connections that do not trade in essentialist thinking that bridge communities in India to the Caribbean.

Manuel says that, "Diasporic identities are inherently unstable and complex entities, in which allegiances to contemporary and ancestral homelands are variously reconciled, weighted, or compartmentalized" (Manuel, "Chutney" 17). This indicates that India, as it exits in the Diasporic Indo-Caribbean imagining is a fictive place, a trope for a place of origin. Since overseas communities' contact with India ceased after the period of indenture, and because of its isolation from the motherland, the emigrants were able to adapt and renegotiate the qualities of "Indian-ness" apart from their physical South Asian contexts. Therefore, India became a place of imagination with Chutney music as a signifier for a new syncretic culture flourishing in its own terms. Chandra Jayawardena puts it as follows,

homeland is not necessarily a fixed geographical entity. It is periodically redefined by historical events and present developments, so that, for example, the creation of Pakistan and Bangladesh need not affect the emigrant consciousness of 'India'. (Jayawardena 430)

According to this, the India of the emigrants no longer exists, so looking for and unearthing remnants is a futile task.

When considering the formation of the koined language of the Indian Labor diaspora in a broad sense, the 1916 text I Even Regret Night: Holi Songs of Demerara provides a clear example of the village chautal tradition as it appears in the Caribbean, before Chutney music burst onto the scene. Originally documented in her 
book Coolie Woman: The Odyssey of Indenture, Gaiutra Bahadur provides a template for understanding the cultural impact of folksong to document life on the plantation. Lalbihari Sharma, the author of the collection of songs performed at Phagwa or Holi time, illustrates in in his use of North Indian syncretic language by writing in a new the formation of localized "plantation Hindi." To me, as the translator of this volume, I see something of South Asian origin growing and transforming in its new Caribbean context.

But the question remains, why is song and its musicality the site of this new poetics? The answer may lie in the fact that the workers brought to the Caribbean belonged to aural traditions and relied on folk transmission of culture. Music, in its connection to poetry, allows for the typical literary devices of rhyme, repetition, rhythm, and allusion to propel performers and listeners into the imagined field through its expectation that arises from form and formal constraints: in Sharma's case, the chautal and in Popo's case, the Bhojpuri chorus and the influence of Calypso.

\section{Methodology and Approach}

My own approach to discussing the poetics of Sundar Popo's works is at once a postcolonial close reading and "retelling of stories that had been previously untold" (Ramnarine, "Brotherhood" 3). Borrowing from Ramnarine and her "engagement with reflections on postcoloniality in terms of condition and moment undertaken in interpreting," (3) I posit the salience of Chutney lyrics as a poetry. I use my own original translations and personal experience in living in Indo-Caribbean space to inform the construction of meaning. I am able to see the slight and subconscious shades of meaning, accessible only to a person of Indo-Caribbean descent capable in Creole, Caribbean Hindi, Indian Bhojpuri, and Western Standard Hindi. Gayatri Chakravorti Spivak in her essay "The Politics of Translation" says that translation is not about a string of synonyms but rather,

is the most intimate act of reading. I surrender to the text when I translate. These songs, sung day after day in family chorus before clear memory began, have a peculiar intimacy for me. Reading and surrendering take on new meanings in such a case. The translator earns permission to transgress from the trace of the other - before memory - in the closest places of the self. (Spivak 398)

It is not my intention to link these songs to past identities or ties to South Asia, but rather to illustrate subjugated mindsets through the intimacies of their poetic expressions. Here my translations are not as a first person inside informant to gain academic trust, but rather as an individual exploring his own poetic inheritance. I attempt to translate the ethos and ethics of the songs through artistic expression, translation, and poetry by answering the questions of Indo-Caribbean identity and poetics after colonialism and in doing so open the possibility of reading these songs as literature with possible feminist and queer stakes. Spivak also states that the translations should be done in order for the writer to understand them as well taking into account the history of the language, as well as the history of the language-in-and-as-translation (403).

It is my intention to present a poetry of Diaspora as rendered through folksong that pays special attention to the generational hegemonies and interactions with colonial mindsets, the continuance and inheritances of domestic violence, sexuality, and alcoholism. This reading works contrary to Manuel's claim previously discussed as I have personal experience in the instructive nature, the conveyance of meaning, and syncretism of Chutney lyrics. Here, I have translated songs performed by Sundar Popo (included five, two in Creole with some Bhojpuri/Hindi inclusion) that have been influential and popular in my own Indo-Guyanese community. They indicate a particular culture of syncretism and Diaspora that is both meaningful and important as a firsthand historical account that can also lend themselves to queer readings considering voice and performance.

As far as these songs are concerned, I have always been close to someone fluent in Guyanese Bhojpuri: my grandmother, her sisters, and neighbors would debate word and song meanings with me. My own limitations to this study are such that Guyanese Bhojpuri is not my first language, and the variety of Creole I speak is two generations removed from her own. I was not born in the Caribbean and have not lived there for any long-term period. I am able, however, to look at the ethos of my grandparents' and parents' generationsSundar Popo's generation-from my own positionality and to discuss how their acculturation has impacted my own. It is through the lens of a grandchild that I attempt to understand these songs as poetry. In doing so I locate myself in the continuing history of this generation as I translate the songs for this study.

Many other performers including Babla and Kanchan, a Bombay based musical duo, have rendered all of the included songs, with the exception of "Nana Nani." Babla and Kanchan enjoyed international success 
with performances across the world, including the Caribbean, Europe, Africa, North America, and Asia. All of the lyrics of the discussed songs may be found in both the original as well as translation in the appendix.

Popo's lyrics reflect ideas of Diaspora in their thematic development, playing with politics of language, gender, sexuality and traditions in transition that demonstrate the psyche of his generation. This includes the inheritance of violence from indenture, the dystopia of the cane field, alcohol dependency, dreams of home and the tensions that arise from adopting a new culture, nostalgia and reimagining kinship ties, and domestic violence. Here the site of poetry as lyric is simultaneous with the production of music; the poetics of Indo-Caribbean folksong are inexorably linked to performance and musicality, as through the nature of the Creole language and its inclusion as the language of medium has socio-political investment in the construction of meaning.

\section{Chutney Translation and Analysis: Bends Towards Meaning}

The first song is important in this discussion as it contributes to Popo's poetics by illustrating the adoption of certain Western behaviors and the problems that his own family encounters including: alcoholism, domestic violence, and Westernization. "Nana Nani" superficially is a song about the singer's maternal grandfather who through the abuse of alcohol accidentally murders his wife. It is composed with the first two lines in Caribbean Bhojpuri and the rest in Creole. The kinship terms are maintained here in the original Bhojpuri. This synthesis of language expounds the theme of cultural blending and the awkward gaps in the older generation trying to assimilate into Creole culture. By including the Bhojpuri, Popo is able to show through its sonorous qualities the meeting of two identities.

Nana Nani ghar se nikale dhire dhire chalte hain, ${ }^{1}$ madiera ke dukan mein dono jake baite hain. ${ }^{2}$

Nana chale age age ${ }^{3}$ Nani goin' behin',

Nana drinkin' white one and nani drinkin' wine.

Since the laborers were sent to work in sugarcane fields, it follows that they were also exposed to rum as it is a byproduct of the cane, as stated by Sidnell, "As a by-product of this industry, rum has been available in quantity in Guyana since the early days of colonial administration" (Sidnell 72). In Bhojpuri and Hindi the terms "madiera" and "wine" refer to any general type of alcohol. Here rum is a trope for Westernization, that is the adoption of Western values and usages of alcohol and the acceptance of Western colonial influence as public alcohol consumption was not traditionally socially acceptable behavior in Hindu/Muslim families. In fact, in my own community, it is still socially taboo for a woman to consume alcohol until drunk. Such behavior indicates "looseness" and a different gendering (Manuel, "Chutney and Indo-Trinidadian Cultural Identity" 33). This consumption also serves to alleviate any type of soulful yearnings, distance from tradition that this generation might be feeling, as the Nani says to the Nana,

... "ole man I feelin' cole,

gimme some white one to wahm up me soul."

Here alcohol serves to placate and numb the Nani's soul from the coldness of the elements, which can specifically bend the reading towards the situation that arises from her adopting Western values (i.e. riding the bicycle).

The next verse illustrates the further embracing of Western culture by the older generation by using the bicycle and the renegotiation of kinship ties. Since Sundar Popo was singing in the 1970s, his grandparent's generation would have been those in the last days of indenture.

Nana ridin' bicycle an' Nani ringin' bell,

Nani look de handle den fall inside de well.

Me Nana so careless he don't kay if Nani drung,

but he jump in de bank he hole on to white one.

\footnotetext{
${ }^{1}$ Grandma and Grandpa leave their home walking slowly.

${ }^{2}$ having gone to the rum shop they both sit inside.

${ }^{3}$ Grandpa goes ahead.
} 
Interestingly, the bicycle makes its appearance in the first verse, as it was invented in the 1800 s and began to become popularized around the world during the period of indenture. Here the bicycle is a signifier of shifting culture through the meeting place that is Caribbean space with the character of the Nani in the public sphere, riding the bicycle and ringing the bell. She is an active participant in the scene. This verse also signifies the shift in kinship ties as the Nana character cares more for his rum, his connection and inheritance from the colonial powers, than his own wife.

When considering gender and domestic violence in Indo-Caribbean space, Supriya Nair in her book Pathologies of Paradise: Caribbean Detours claims that historically, the Indo-Caribbean woman appears as a subject written in the fiction of mostly male writers. She writes,

Indo-Caribbean women became ethnic markers of difference, generally seen as more docile and pliable participants in a patriarchal system that brought from India and only momentarily interrupted by the disruption of their passage to and settlement in the Caribbean. (Nair 60).

From this, Nair claims that the patriarchal inheritance of domestic violence and gendered abuse originated in various Indian (South Asian) contexts and was brought into the Caribbean with the emigrants. As in the book No Pain Like This Body, written by Harold Sonny Ladoo in 1972, documents domestic violence in a fiction, the themes of domestic violence and alcoholism prevails. Here the character of the twelve-year old Balraj narrates the scene of Ma's abuse-a domestic violence written about by a man and narrated by a boy, showing Nair's original point.

Indeed, Gaiutra Bahadur corroborates this particularity of domestic violence's relation to Indian indenture in her book Coolie Woman: The Odyssey of Indenture. Bahadur states,

Between 1859 and indenture's end in 1917, more than 167 women were killed by intimate or wouldbe intimate partners in Guiana. Infidelity-or, the fear of it-motivated the crime in most cases, colonial authorities claimed ... The murders were part of the Englishman's evocation of empire's uncivilized backlands-a surreal landscape of grisly, almost mythological horrors. (Bahadur 108-109)

In this way the stereotype of the Indian man in the Caribbean of violent was created and perpetuated by people who wanted to continue to produce a social distance between themselves and the "coolies."

Yet Nair goes on to say that "the term 'patriarchy' also has to be revised and only provisionally applied to the Indo-Caribbean male ... as women writers often demonstrate that the term does not imply the unilateral power of all men, particularly when ethnic, class, and sexual contexts shift their status" (Nair 60). In this way Sundar Popo's "Nana Nani" takes on a nuanced dimension of various patriarchal violences: that of the Indian patriarch and that of the colonial patriarch-the later of which controlled the numbers of women arriving in the British colonies.

In the next verse of the song the old ways of the laborers meet with the new ways of colony as the grandparents go to get goat meat, either as a sacrifice (as both Kali centric Hindu worship and Islam practice the ritual sacrificing of goats) or as a food. Here, under the influence of alcohol and enduring indenture, the Nana cuts the Nani's throat and is arrested by the police-obvious outsiders either in terms of national identity or cultural practice.

Me Nana an' me Nani went to tie a goat,

me Nana make a mistake an' cut out Nani troat.

De police tol' me Nana he couldn' get no bail,

de pull de po' ole man and put 'em in de jail.

The Nana is unable to get bail to ensure his freedom until the trial. This drama is a direct meeting of indentured Indian culture clashing with local Caribbean law and culture. Here Indians are both outside and unworthy of sympathy as well as inside as trying clumsily to adopt a new Caribbean Creole home culture (Ramdin 269), but more than this there is the semiotic ambiguitiy of the Nana's "mistake." Does "mistake" here mean "accident" or does it mean "that which is a cultural norm that violates law?" The speaker is aware of the presence of wife murders and the stereotypes of the Indian male and choses to show the consequences of the Nana's "mistake" instead of to use a more precise word.

The poem concludes with the speaker's epiphany that he is in a sense orphaned; that he is alienated from his home culture and Indian identity. His last words indicate that he has to begin drinking with his 
"companion" of unspecified gender and relationship. Overall, these lyrics identify the challenge of the older generations encountered in their adopting the Creole culture of the Caribbean at the time and the various inheritances of patriarchal violence. These are the tropes of Diaspora in Popo's construction of meaning throughout the song. His use of mixed language, a discussion on changing kinship ties, an orphaning from Indian culture, the loss of the old, the dangers of Westernization though the use of alcohol and domestic violence through surviving indenture, illustrate his sense of poetics in terms of this new Caribbean hybridity and the problematic of identity politics for the indentured generation.

In the next song, "Kaise Bani," Popo discusses his new home in Diaspora as a synthesis of the East Indian and the West Indian. He does this by including synecdoche for these through instrumentation as well as the combination of languages in the lyrics. The drum and music are a symbol of India whereas the rum, as previously discussed, stands in for the cane field and the West Indies. In fact, throughout the song text, whenever the speaker travels away from home some calamity ensues. When he goes to visit his friend, he is greeted with a knife; when he travels with his "dahling" he suffers a plane crash into the cane field.

I went Sunday Blandy to meet Lal Bihari,

I pull out me kudari ${ }^{4}$ an' see a banki-dhari. ${ }^{5}$

Me an me dahling were flying in a plane;

de plane catch a-fiyah an we fall inside de cane.

Here, his hybridity and Caribbean syncretism is inevitable, as he cannot escape his physical location (Trinidad). This illustrates that Trinidad and the Caribbean are inalienable aspects of the subject's identity. Ironically, the part that's missing in his song is the "bottle of rum," which may indicate that what is really missing is an investment in his new location:

I beatin' me drum when I singin' me song;

the only tings a missin' is me bottle a rum.

His language in this song is again mixed with a refrain in Bhojpuri and the verses in Creole that include a Bhojpuri lexicon significant of cane labor but inexorably linked to Trinidadian nation language. The inclusion of the Creole here identifies both the hoe and a special curved knife used to cut cane; both indicated as tools to perpetrate violence against another person. Here, the site of the labor, the cane field is also the site of another trauma-the site of a plane crash. He is flying in the plane with his "dahling"; his relationship with this person is not clear-is it a lover, or is it his wife, possibly a same-gendered partner?

Perhaps the most interesting aspect of this song is the last verse where Popo includes "Jack and Jill" and "Little Jack Horner":

Jack an' Jill went up da hill to fetch a pail of wota';

Jack fell doung and broke his croung an' Jill came tummlin' aftah.

Little Jack Hahnah sit in a conah eatin' his Christmas pie;

he put in his tumb an' pull out a plum an' said, "What a good boy am I."

Here the English verses are Indianized through instrumentation and Creole pronunciation. Popo uses this English nursery rhyme strategically in order to wage a kind of mimicry that challenges the hegemonics of Western imperialism and British colonization. The appearance of the Indianized nursery rhyme (through its tune) is not Bhabha's "partial presence" of the colonized where the colonized individual is a subjugated disappearing object. Rather, Ramnarine says of instances like the Indianization and emergence of colonial forms as read through the English nursery rhyme, that this shows evidence of colonial "white scars" as the foundation of "Indo-Caribbean identity was laid by nineteenth-century British colonial policy" (Ramnarine, "Brotherhood" 5). But another issue at stake here is Bhabha's concern with mimicry. Is the effect of Popo mimicry of the English rhyme "'normalizing' the colonial state or subject, the dream of post-Enlightenment civility alienated its own language of liberty and produces another knowledge of its norm" (Bhabha 123)?

\footnotetext{
${ }^{4}$ hoe.

${ }^{5}$ a person who wields a curved knife used to cut cane.
} 
It may also serve as a meta-discourse on the inclusion of the English language in Chutney music, Popo's original style, as well as the syncretism of English and Indian poetics-a syncretism allowed by the Caribbean's colonial inheritance. Here his poetics and his outlook, in terms of his own musicality and linguistic practice throughout the song are Chutneyed in that they meaningfully include and incorporate his various languages and cultural and national identities so origins are obscured through the churning and chutnification of song. In this way, this remnant corresponds to subcontinental Indian/South Asian elements of Chutney music in that its origins are marked but wholly imaginary given the process of creolization that occurs in the Caribbean.

This example of intertexuality in performative spaces shows the influence of the musical traditions that developed in Trinidad outside of Indo-Trindadian spaces. The Mighty Sparrow, a renowned Calypsonian, sings in his song "Dan is the Man (in the Van)." In this song, The Mighty Sparrow lays bare the ironies of colonial education in Trinidad by using British nursery rhymes. Such a technique shows the ways in which "official," standardized language was being used to critique colonial education. The Mighty Sparrow sings,

De poems an' de lessons dey write an' send from England

impress me dey were trying to cultivate comedians.

Comic books made more sense: you know is fictitious, without pretense.

Cutteridge wanted to keep us in ignorance.

Tell me if dis eh chupidness,

Humpy-Dumpty sat on a wall

Humpy-Dumpy did fall

Goosey, goosey gander,

where shall I wander? (Sparrow)

From this excerpt of his famous Calypso, the sonic landscape of Trinidad comes into focus. From this account we are able to make a connection of strategies: Sundar Popo was influenced not only by Bhojpuri poetics and poetic constraints but also influenced by the music of the Calypsonians around him. In this way, through the exposing of influence does Popo's art directly evidence creolization: syncretic traditions of an imagined origin interacting with the local socio-historical context of Sundar Popo's present Trinidad.

To contextualize the syncretism that this song evidences, I turn towards Stuart Hall's "Thinking the Diaspora: Home-Thoughts from Abroad" where he states of beginnings and ends in the Caribbean, "Foundational myths are, by definition, transhistorical" not only outside of history by fundamentally ahistorical" (Hall 546), and this is related directly to identity formations. The forms of identity emerge through a negotiation of the Caribbean's violent past with its "complex interweaving and fusion in the furnace of colonial society, of different African, Asian, and European cultural elements" (547) into the present. Hall believes in the ubiquity of differance and hybridity and uses Derridian notions of differences not working though binaries but "[doubled] up as places de passage, and meanings that are positional and relational, always on the slide along a spectrum without end or beginning" (548)-a metaphor that Hall uses to describe identities in the Diaspora. Caribbean culture is "driven by a diasporic aesthetic" (549) where purity and hybridity run into each other, interacting with colonial power relations. Since globalization is not new, but rather began during the age of European "exploration," the Caribbean became a place of early globalization and market trade wherein today national boundaries do not serve what Hall calls "Caribbean culture." Therefore, the poetics that occur in these songs influence the larger society around them.

The next poem whose meaning is excavated is "Ham Na Jaibe Sasur Ghar Me Baba." This song may have several readings for meaning: superficially it describes the ordeals that a new bride faces in moving to her inlaws' home. She is beaten while her father-in-law is drunk. There is a threat of sexual violence and rape here where the bride is introduced to the sexual economy of her new home, and by her discussion it is inferred that there is a marked difference here from her own paternal home. The sexual economy of the new home is one where the in-laws serve as the models. Their behavior is to be the new "cultural" norm of the home. She must suffer loneliness and adapt to the feelings of abandonment she feels as she appeals to her father.

I will not go to my father-in-law's home, father

I am afraid (my life has frozen), father.

In this instance there are also traces of nostalgia by the empty space, and the things that are not said and the fear that she endures. In fact, she endures so much that her life [force] is frozen with fear. 
Another reading for this adjusting process to a new home is in the in-laws' home-a new home in Diaspora whereas the familiar, familial home is India. In this instance it is noteworthy that there is a complete omission of life at the original home, just a remark of the differences in regards to culture and sexuality that the new bride must endure and to which she must acculturate. Here the "baba" that she refers to is India and the "sas/sasur" is the new context, in Sundar Popo's case Trinidad, but broadly, the Caribbean.

Popo begins with the female speaker singing about the presence of rum in the home,

Every day my father-in-law drinks alcohol

every day my mother-in-law pokes me with a stick.

Joy Mahabir in her article "Poetics of Space in the Works of Mahadai Das and Adesh Samaroo," writes about rum and its usage in the Caribbean as both a placating agent and as an option for indentured laborers and their descendants to escape from the horrors of socio-economic destitution. She does this through the lens of chutney music that is written mostly in English. This song adds to the archive that she begins to excavate in its treatise of rum. In this Sundar Popo song the father-in-law looms as a drunken both physical and sexual threat in the home a he dinks, watches the daughter-in-law and beats the mother-in-law in the song lyrics.

The mother-in-law behaves in a manner questionable to the bride as she describes the scene,

Every day my mother-in-law shows her goods,

having seen this, my father-in-law watches greedily.

Mother-in-law rocks father-in-law, father

while he lies, adorning her lap, father.

She is unfamiliar with this behavior because she has not yet been married, but more importantly, since the supposed origins of this type of singing was from the matkor where women instructed the bride-to-be in sexuality, it shows such instruction and also serves as prolepsis to married life as a metaphor for life after indenture.

Patricia Mohammed writes about matkor or matikor as a trope that responds to Indo-Caribbean femininity as its homosocial space. She writes,

Here, in a primarily female space, the young bride would be introduced to the pleasures and vagaries she must expect of married life, amidst much ribaldry and teasing in the form of song. In this gathering of women, young and old, stories were also shared, experiences passed on through humour, and solidarities built between generations of women. The songs that were acted out, which were both sensually and sexually expressive, became known as chutney songs. (Mohammed 11)

Sundar Popo's form in this song is one that echoes the matkor which was typically seen as an ancestor to chutney music. His new Chutney form holds the history of its predecessor and responds to the initiation of the wife's dharmic and assumed duties under the patriarchal, nation-reinforcing institution of marriage.

Yet what Mohammed goes on to indicate about femininity and female homosocial space is echoed by Bahadur and Nair, the latter of whom states that, "Wife murders became a dominant symbol of IndoCaribbean identity and although domestic violence is as pervasive in the Caribbean as in many other cultures, it achieved a notorious place in Indo-Caribbean history" (Nair 61). This sexualization of females is marked by a historical footnote which states that due to the shortage of women in the initial days of the period of indenture, the few women in the colonies were in high demand, often separating from her original spouse to take up residence with another man. Also, there were many reported incidents of women who were forced into sexual relationships with the owners and supervisors of the sugarcane estates (Vatuk, "Protest Songs" 228).

The speaker's complaints in this poem are not against her spouse, one that may have very well been chosen for her. The listener knows this as Indian custom: the bride lives the traditional role by going to live with her new husband's parents. To live with the parents of the groom was the traditional residence after arranged marriages (Khan 12). In this entire song her husband is nowhere to be seen when all of these activities occur. If her husband were present would she have such cause for concern, or would his presence alleviate the violence she fears in her new home? The speaker continues,

Father-in-law beats his wife, father, in their small hut, father. 
Father-in-law beats his wife, father,

having taken his own stick, father.

According to this reading of the text, in Diaspora the laborer would have no support system to shield her/ him from the [sexual] abuse from the landowners and supervisors as one of the holons of patriarchal rule.

This illustrates Nair's notion of a shifting patriarchy, though the particularities of gendered violence are important to remember. Popo sings as a woman in this song using a form that relates to the matkor, female homosocial space where sexuality is performed in an instructive manner. Domestic violence appears in this song after the mention of rum in the first stanza and threatens both the speaker and the mother-in-law. The mother-in-law is not safe from the father-in-law, who represents complete authority. The woman is not only the female indentured laborer but extends to include the man as the singer. Is the speaker in Popo's song a man singing a woman's song? Is there a possibility for a queer subject? This poem echoes the themes of abandonment, violence, marriage, the changing of kinship ties, loneliness and the misogynist sexualization of women as tropes for the experiences of Diaspora.

The song "Cadar Bicao Balama" points towards an extramarital affair where the woman expounds the virtues of her new lover. It is inferred that the lover is separate from the husband as the speaker in the poem speaks of her own father-in-law (more) and then changes in the next line of the couplet to "our" (hamar). She has already relocated to her new home (her husband's paternal home) and possibly portrays a female sexuality where the woman selects her partner. On the other hand, it can also illustrate the ways in which men fantasize about women, as Popo's speaker sings from a woman's subject position. The intention of this song is unclear and arguably, it can be read as both patriarchal in its dealing with women's sexuality or feminist in the matkor form being brought into the public sphere.

This is a particularity of Chutney music as a genre-it has been written about as representing a kind of loosening of "traditional" Indian patriarchal reins in its performance and subject matter. Aisha Mohammed in "Love and Anxiety: Gender Negotiations in Chutney-Soca Lyrics in Trinidad" says, "[Indo-Caribbean] women reset these [patriarchal] parameters by binging private traditions into public spaces and expressing their sexuality vibrantly though song and dance" (A. Mohammed 8). By women bringing matkor traditions to the public sphere, a new expression of Indian woman sexuality emerges.

The song-poem continues,

Lay down a sheet, love

if tired we can remain asleep in peace.

Here the speaker instructs her partner to lay a sheet down, which is suggestive and sexually connotative by nature, echoing the ribaldry of the matkor music and the form of the Chutney song-poem. This can also be read to frame the situation of those who settled the new colonies instead of returning to India after their contracts were up, in fact, it would have been from these very settlers from which Popo is descended from as well as from whom he learned these songs.

Here, the general attitude is that the new situation in Diaspora, or the creation of a third space-not the parental home, not the marital home, but a new place where the woman can enjoy her lover-is one better than the original situation.

My father-in-law has two mahals, the most beautiful is our palace.

My father-in-law has two beds, the most beautiful is our sheet.

My father-in-law has two sons, the most beautiful is my lover.

My father-in-law has two daughters-in-law, the most beautiful is my life.

Whether it is the actual palace, the trappings (the beds) or the individuals (either the sons or their wives), the speaker insists that the most beautiful is indeed this new third space co-created by the bride and her lover.

Here this third space is a stand in, a metaphor for the new life in the Caribbean, which is not the traditional home, nor a place where the home culture remains unchanged. The trope of the home, its trappings: 
be they sheets, the house itself, the bed or the people inside that constitute material and familial culture, represent the creation of a new space, a new syncretic culture altogether. What remains are the titles for the new kin and what changes according to the poem text is the selection of a sexual partner by the female character who is supposedly narrating this through music. Here a new home, or Diaspora, is signified through the poet's usage of the objects and relationships occurring in the domestic sphere.

The final poem that signifies a new home, the syncretism of Diasporic culture and a Chutneyed poetics is "Rat Ke Sapana," whose title means "night's dream." Here the poet dreams of a lover who shows her a home signified and alluded to by a neem tree, its courtyard as well as a dark shadow: the absence of an heir: the ultimate trophy of patriarchy. The speaker must shoulder this burden and continue the line of the new patriarchy she has joined through marriage. This lover is a dream figment, who has no place in the real world so through this, the speaker yearns for this fulfillment. Here the lover represents a new home that needs populating. At first this shadow is comfortable and offers relief to the suffering couple:

in my courtyard there is no neem tree

my lover makes me sit in the shadow of a home.

Instantly there is a comparison made between the new home and the old: there is no neem tree to offer the comfort of the familiar. This problem is assuaged by the resourceful use of the physical house's shadow. Later the speaker realized that this shadow is also a metaphor for the lack of a male heir and it's her marital duty to create one. Here she is without agency, a forced victim of the patriarchy.

The interpretation of the dark shadow comes from the line,

in my in-laws' home, there is no brother or nephew,

my lover places the pain/hope of his home on me.

In this excerpt, the word used to signify "pain/hope" is "aafat/aasaa" which the poet switches between when the verse is repeated. Both the hope and the pain arise from the need to populate a new location. This speaks to the mixed emotions concerning the creation of a new space where the speaker is forced to take "steerage of the wheel" of her husband's home.

in my in-laws' home there is no celebration for a brother-in-law

my lover made me steer the wheel of his house.

What separates this new home from the old one, or one where the speaker is familiar with the culture, is the fact that the culture is changing and the new bride will be responsible for the creation of a new home. Moreover, she will be creating and sustaining a new culture. This, due to the positionality of Popo's teacher (the old women of his family and his community) refers to the new creation of home in Diaspora (Ramnarine, "Historical Representations" 13). Due to the alienation from and the abandonment by India as a country and cultural originator, the indentured peoples who stayed behind were forced to create a new space and a new culture drawing from collective memory and the new landscape.

Whether this process was conscious or subconscious is not as important in the discussion of the poetics involved in creating and relating meaning as is the trauma that it induced. Artistic expression here happens before its theorization. The creation of a new home with fragments of songs and traditions in a new landscape without familiar foliage and community in contact with several others in the Caribbean context forced the syncretism and koinization of language and culture. The poetics of this song convey shades of feeling regarding the shifting landscape, cultural shift and direct action in the creation of home in the Diaspora, without a concerted need for a return to India.

To further complicate the gendered reading of this song, however, what must be noted is the fact of Sundar Popo's gender identity: that of a cisgender man who sings these songs as longing of male companionship. The dawning of a woman's voice, or perhaps even a voice and positionality opens the door to a queer potential and possible queer readings of these songs. Judith Halberstam in "Global Female Masculinities" considers imagining the global interactions to be based solely on Western/American epistemologies and asks about what happens when in the cisgender heteropatriarchal system views the body of the queer other. In the case of the Sundar Popo songs, the view of postcolonial masculinity is not addressed directly in his appropriating of voice and thus allows the potential of transgressing normative gendered readings of Chutney music.

What I mean here specifically is that the hegemonic power in theoretical understandings of LBGTQ identities fall in favor with the United States rendering non-Western constructions of gender invisible and "down 
plays transgenderism in other contexts" (Halberstam 346). Halberstam locates this problem in "anthropological fascination with gender deviance, focus on gender variant "women" rather than female to male transgenders, the feminist problem of 'looking for lesbians,' and global transgenderism as 'anachronistic." Listeners cannot look away from the queer lyrics staring out from Popo's lyrics, no can they assign any queer label to the speaker without fear of anachronism or cultural chauvanism.

As in these five examples queer possibility opens itself to interpretation, one possible way of reading these texts can be through what Gayathri Gopinath calls retrospectatorship, or "perverse spectatorship" (Gopinath 95) in which expectation of the audience is thwarted and homoerotic possibilities surface through this type of revision-while-watching. This grants spectatorial agency to queer folks who access these texts, allowing people in the present to see themselves represented by texts in the past.

Gopinath uses her queer lens to search within Bollywood for the song and dance detached from the film narrative and circulate within queer spaces (101). Sundar Popo's words have this velocity-a meaning that is marked in gender possibilities. This allows the reader/viewer to not necessarily look for characters that explicitly mark deviations from gender/sexual normative practices but allows space for queer potential and possibilities (103). With this practice of reading/viewing text "home" space is also a space where queerness can be read back into-so "home" is no longer explicitly homophobic, rather queers have agency in a diaspora that's remembered "and reframed as the locus of queer desire, pleasure, and identification" (113). In various South Asian diasporic contexts, the text of the music, as Gopinath illustrates, is in a type of performance that allows for fluidity and movement. Chutneyed poetics in Sundar Popo's case allow for the reader to imagine a queer past and present for the reader/listener when looking back at the lyrics and the original intentions behind them without perpetrating violence against the speakers.

\section{Diaspora as Chutney}

The language is important as a metaphor for both limits of the ancestral connections and makeup: the English of the colonizers, the Pidgin and eventual Creole of the Africans and Indigenous people and the Bhojpuri of the indentured laborers. The themes and poetics are indispensible to creation of meaning: tropes and stand-ins for home and the syncretism of a new culture in Diaspora. The metaphor in the moniker, that of chutnification is one that is apt in the Caribbean context to describe the music, the language, and the process of Creolization. Since chutney as a pickled mango relish comes from mangoes that are squeezed, dried, spiced, and fermented, and since the change to the flavor in mango undergoes a transformation there is no separating out the constituent spices from the oil. Indeed, long after the chutney is eaten the vessel that bears the relish will be indelibly marked with the scent of the pickle. So too is the metaphor of chutney for the music of Sundar Popo marked with his environs and histories.

As evidenced by these five songs recorded in the 1970s by the singer Sundar Popo, the creation of a new home, a third space, is marked by the comparisons of the origin with the new: there are both remnants and new creations. Since the cultural matrix in the Caribbean was shifting, it follows that the constructions of home encountered in the oral literature of the time illustrate and reflect domestic themes of "traditional" Indian culture. Here the term Indian is used to reflect the India of the indentured laborers and not the India of today and the representations of "home" as portrayed and discussed by the text illustrate the shifting and re-signification of cultural mechanisms in a syncretic, specific Indo-Caribbean context. Home is a place, as defined by the poetics of Diaspora, that is a meeting place of Eastern and Western values, objects, kinship ties, and sexualities. It is a place that is at once feared as well as embraced without the desire to abandon the new matrix, bucking the normalization of colonial knowledge in terms of language.

These poems serve to illustrate the mindset and construction of poetics of the indentured laborers as they tap into the trauma of location and exist in a nexus between the old and the new while providing the possibility of inclusion in the Caribbean poetic landscape. Despite the notion that Chutney is only a musical genre with close to meaningless lyrics, I have been able to see the joints and hinges of the creation of a new identity, in a specifically Caribbean idiom through meaning in Sundar Popo's songs. It is my hope to mitigate such epistemic and discursive violence by including the original texts, written in Creole and highlighting the significant cultural references as well as various contexts of words and phrases in translation from the original Bhojpuri. Due to the complex nature of India's location of in the Diasporic mind, much of what flourishes can be gleaned through the poetic expression that occurs in the song lyrics of the popular music that descended from the meeting of South Asian folk traditions and a new colonial context. Indeed, these songs open a space for many people to draw from and see themselves represented by: the woman, the queer, and the man. The homeland becomes a mythological location and is no longer a home outside of the descriptions via negativa. The archive of Chutney music songs read as postcolonial literature illuminate another important Caribbean ingredient. These song-poems 
straddle boundaries of genre, are amalgamative, express Caribbean creativity, are adaptive, enduring and furthermore, living.

\section{Appendix of Original Translations \\ Nana Nani}

Nana Nani ghar se nikale dhire dhire chalte hain, ${ }^{6}$

madiera ke dukan mein dono jake baite hain.?

Nana chale age age $e^{8}$ Nani goin' behin',

Nana drinkin' white one and $\mathrm{N}$ ani drinkin' wine.

Nana ridin' bicycle an' Nani ringin' bell,

Nani look de handle den fall inside de well.

Me Nana so careless he don't kay if Nani drung,

but he jump in de bank he hol' on to white one.

Nana smokin' tubacco an' Nani cigarette,

de rain stahted fallin' de bot a dem get wet.

Me Nani tell me Nana, "ole man I feelin' cole,

gimme some white one to wahm up me soul."

Me Nana an' me Nani went to tie a goat,

me Nana make a mistake an' cut out Nani troat.

De police tol' me Nana he couldn' get no bail,

de pull de po' ole man and put 'em in de jail.

When I get de message I fall down in a drain,

fo' I know I haven' got no Nana an' Nani again.

Me Nani dead an' gone, me Nana goin' to hang,

so I have to get one fo' my companion.

\section{Kaise Bani}

Kaise bani, ${ }^{9}$ kaise bani, kaise bani, kaise bani, phulowri bina chatney kaise bani ${ }^{10}$

I went Sunday Blandy to meet Lal Bihari, I pull out me kudari ${ }^{11}$ an' see a banki-dhari ${ }^{12}$

Me an me dahling were flying in a plane;

de plane catch a-fiyah an we fall inside de cane.

I beatin' me drum when I singin' me song; the only tings a missin' is me bottle a rum.

Jack an' Jill went up da hill to fetch a pail of wota';

Jack fell doung and broke his croung an' Jill came tummlin' aftah.

Little Jack Hahnah sit in a conah eatin' his Christmas pie;

he put in his tumb an' pull out a plum an' said, "What a good boy am I."

\section{ham nā jāibe sasur ghar mẽ bābā}

ham nā jāibe sasur ghar mẽ bābā

jiyarā jaṛ gail hamār bābā

\footnotetext{
${ }^{6}$ Grandma and Grandpa leave their home walking slowly.

${ }^{7}$ having gone to the rum shop they both sit inside.

${ }^{8}$ Grandpa goes ahead.

${ }^{9}$ how it's made.

${ }^{10}$ a fried snack is made without chutney.

${ }^{11}$ hoe.

12 a person who wields a curved knife used to cut cane.
} 
roj roj sasur darū pīat he

roj roj sās more lakrịi kõcat he

roj roj sās mor cijawā dikhāwe

dekhke sasur jiyā lalcāwe

sās jhulāwe sāsurwā ke, bābā

apnī godī sajariyā pe, bābā

sasur pīte sasuiyā ke bābā

apnī choțī jhopariyā mẽ bābā

sasur pīte sasuiyā ke bābā

leke apni lakariiyā se bābā

I will not go to my father-in-law's home, father

I am afraid (my life has frozen), father.

Every day my father-in-law drinks alcohol

every day my mother-in-law pokes me with a stick.

Every day my mother-in-law shows her goods,

having seen this, my father-in-law watches greedily.

Mother-in-law rocks father-in-law, father

while he lies, adorning her lap, father.

Father-in-law beats his wife, father,

in their small hut, father.

Father-in-law beats his wife, father,

having taken his own stick, father.

\section{cadar bic $\overline{\mathbf{a} o}$ balamā}

cadar bicao balamā

nind lage chain soye rahana

more sasur $\bar{j}$ ke dū dū mahalliya

sab se sundar hamār mahalā... cadariyā

more sasur $\bar{j}$ ke dū dū palangiyā

sab se sundar hamār balathā... cadariyā

more sasur jī ke dū dū bețawā

sab se sundar hamār balamā... cadariyā

more sasur $\bar{j}$ ke dū dū patohiya

sab se sundar hamār jiyarah... cadariyā

Lay down a sheet, love

if tired we can remain asleep in peace.

My father-in-law has two mahals,

the most beautiful is our palace.

My father-in-law has two beds,

the most beautiful is our sheet.

My father-in-law has two sons,

the most beautiful is my lover.

My father-in-law has two daughters-in-law,

the most beautiful is my life. 


\section{rāt ke sapana}

rāt ke sapanā dikhāwo piyā hamko

nā more ãgane mẽ nimiyā ke perdwa

ek ghar chāyā bithāiyā piyā hamko

nā more nahiyar mẽ bhaiyā bhatīiā

ek ghar aafat/aasaa karāiyā piya hamko

nā more sasure mẽ lahura devarwā

eke ghar pahiyã pakardāyai piyā hamko

Night's dream, show me my lover.

in my courtyard there is no neem tree

my lover makes me sit in the shadow of a home.

in my in-laws' home, there is no brother or nephew,

my lover places the pain/hope of his home on me.

in my in-laws' home there is no celebration for a brother-in-law

my lover made me steer the wheel of his house.

\section{Competing Interests}

The author has no competing interests to declare.

\section{References}

Bhabha, Homi. The Location of Culture. New York: Routledge, 1994. Print.

Gambhir, Surendra. Guyanese Bhojpuri: East Indian Speech Community in South America. Chicago: University of Illinois (Doctoral Thesis), 1981. Print.

Gopinath, Gayatri. Impossible Desires: Queer Diasporas and South Asian Public Cultures. Durham: Duke UP, 2005. Print. DOI: https://doi.org/10.1215/9780822386537

Halberstam, Judith. "Global Female Masculinities." Sexualities, 15(3-4): 336-54, 2012. Web.

Hall, Stuart. "Cultural Identity and Diaspora." The Post-Colonial Studies Reader, Ashcroft, Bill, Griffiths, Gareth and Tiffin, Helen (eds.), 435-438, 2006. New York: Routledge. Print.

Hall, Stuart. "Thinking the Diaspora: Home-Thoughts from Abroad." Postcolonialisms: An Anthology of Cultural Theory and Criticism, Desai, Gaurav and Nair, Supriya (eds.), 543-560, 2005. New Brunswick: Rutgers UP. Print.

Jayawardena, Chandra. "Culture and Ethnicity in Guyana and Fiji." Man: New Series, 15(3): 430-450, 1980. Print. DOI: https://doi.org/10.2307/2801343

Khan, Aisha. "Juthaa' in Trinidad: Food, Pollution, and Hierarchy in a Caribbean Diaspora Community." American Ethnologist, 21(2): 245-269, 1994. Print. DOI: https://doi.org/10.1525/ae.1994.21.2.02a00020

Manuel, Peter. "Chutney and Indo-Trinidadian Cultural Identity." Popular Music, 17: 21-43, 1998. Print. DOI: https://doi.org/10.1017/S0261143000000477

Manuel, Peter. "The Construction of a Diasporic Tradition: Indo-Caribbean 'Local Classical Music'." Ethnomusicology, 44(1): 97-119, 2000. Print. DOI: https://doi.org/10.2307/852656

Mesthrie, R. Language in Indenture: A Socio-Linguistic History of Bhojpuri-Hindi in South Africa. London \& New York: Routledge, 1992. Print.

Meyers, Helen. Music of Hindu Trinidad: Songs from the Indian Diaspora. Chicago: University of Chicago Press, 1998. Print.

Mohammed, Patricia. "Changing Symbols of Indo-Caribbean Femininity." Caribbean Review of Gender Studies, 6: 1-16, 2012. Print.

Niranjana, Tejaswini. Mobilizing India: Women, Music, and Migration Between India and Trinidad. Durham: Duke UP, 2006. Print. DOI: https://doi.org/10.1215/9780822388425

Popo, Sundar. Come Dance with the Champ. Windsor Records, 1979. CD.

Popo, Sundar. "Raat Ke Sapana." Hot and Spicy (Chutneys). Windsor Records, 1980. CD.

Ramdin, R. Arising from Bondage: A History of the Indo-Caribbean People. New York: New York University Press, 2000. Print. 
Ramnarine, Tina. "Brotherhood of the Boat: Musical Dialogues in a Caribbean Context." British Journal of Ethnomusicology, 7: 1-22, 1998. Print. DOI: https://doi.org/10.1080/09681229808567270

Ramnarine, Tina. "Historical Representations, Performance Spaces, and Kinship Themes in Indian-Caribbean Popular Song Texts." Asian Music, 30(1): 1-33, 1998-1999. Print. DOI: https://doi.org/10.2307/834262

Sidnell, Jack. "'Primus Inter Pares': Storytelling and Male Peer Groups in an Indo-Guyanese Rumshop." American Ethnologist, 21(1): 72-79, 2000. Print. DOI: https://doi.org/10.1525/ae.2000.27.1.72

Spivak, Gayatri Chakravorty. "The Politics of Translation." The Translation Studies Reader, 397-416, 2000. New York: Routledge. Print.

The Mighty Sparrow. "Dan is the Man (in the Van)." YouTube, 15 May 2018. https://www.youtube.com/ watch?v=24rQOy2HZFE

Tiffin, Helen. "Post-colonial Literatures and Counter-Discourse." The Post-Colonial Studies Reader, Ashcroft, Bill, Griffiths, Gareth and Tiffin, Helen (eds.), 99-101, 2006. New York: Routledge. Print.

Vatuk, Ved Prakash. "Craving for a Child in the Folksongs of East Indians in British Guyana." Journal of Folklore Institute, 2(1): 55-77, 1965. Print. DOI: https://doi.org/10.2307/3814112

Vatuk, Ved Prakash. "Protest Songs of East Indians in British Guiana." Journal of American Folklore, 77(305): 220-235, 1964. Print. DOI: https://doi.org/10.2307/537745

How to cite this article: Mohabir, R 2019 Chutneyed Poetics: Reading Diaspora and Sundar Popo's Chutney Lyrics as Indo-Caribbean Postcolonial Literature. Anthurium, 15(1): 4, 1-17.

Published: 12 February 2019

Copyright: $\odot 2019$ The Author(s). This is an open-access article distributed under the terms of the Creative Commons Attribution 4.0 International License (CC-BY 4.0), which permits unrestricted use, distribution, and reproduction in any medium, provided the original author and source are credited. See http://creativecommons.org/licenses/by/4.0/. 